\title{
Development of Science Teaching Books Based on Fun Experiments for Early Childhood (5-6 year-olds) in the Kindergarten of Kutalimbaru Subdistrict, Deli Serdang Regency
}

\author{
Hestika Dewi Sitepu \\ Basic Education Study Program, \\ Postgraduate School \\ Universitas Negeri Medan \\ Email : siteputika836@gmail.com
}

\author{
Rosmala Dewi \\ Lecturer of Postgraduate School \\ Universitas Negeri Medan \\ Medan, Indonesia
}

\author{
Wildansyah Lubis \\ Lecturer of Postgraduate School \\ Universitas Negeri Medan \\ Medan, Indonesia
}

\begin{abstract}
This research is motivated by the availability of textbooks that are not in accordance with the needs and conditions of the child's environment, so that the introduction of science learning for early childhood has not been carried out optimally. The aim of this research is : 1) To know the feasibility of using experimental science-based textbooks is fun for early childhood (5-6 years old) which was developed. 2) To know the effectiveness of the development of textbooks produced in improving cognitive abilities in children aged 5-6 years. The subjects in this study were group B students in the Islamic Kindergarten Integrated MTTQ School Kutalimbaru 2018-2019 of Academic Year, totaling 36 students. This type of research is research and development (R\&D). The development of textbooks is based on 4-D model development research (Four D Models) according to Thiagarajan which includes 4 stages namely the defining stage (define), design, development, and disseminate. The research results obtained that (1) The level of feasibility of based science textbooks is fun based on : a) the results of the validation of the material expert on the feasibility of the contents of the developed textbooks are included in the "Good" category. b) Practical results from teachers stated that all teachers need science-based textbooks that are fun experimentation in the learning process because the books provided are not only for students but have guidelines in the form of teacher's books. (2) The results of the effectiveness of the textbooks developed showed that the cognitive abilities of children after using science-based textbooks for experimentation were higher than just using magazines and posters as learning media. Where the average initial value of the child is $\mathbf{5 0}$ and the final test increases to 75.50. This proves that there has been an increase in the value of children for cognitive development by 25.50 .
\end{abstract}

Keywords : Textbooks, Experiment Based, Cognitive Ability.

\section{INTRODUCTION}

Education is one form of the embodiment of human culture that is dynamic and full of development. Suyadi stated that education is an attempt to change the behavior of individuals (students) in a controlled environment (Suyadi, 2010:7). Controlled environment is a positive environment that is created through interaction with the closest people (family or neighbours) and can be realized through good relations between parents and children, teachers with students and the relationship of children and their friends. This can be a media for achieving educational goals that designed through early childhood education. Law No. 20 of 2003 concerning the National Education System Article 1 paragraph 14 explains that:

"Early Childhood Education Programs (PAUD) is a coaching effort aimed at children since birth to the age of six years, carried out through the provision of educational stimuli to help physical and spiritual growth and development in order that children have preparation in entering further education (Sisdiknas, 2015 : 4)."

This statement can be said as an implementation of long life education. Because education is one of the necessities of human life as a cultured living thing, with education people will encounter changes towards rapid progress. For this reason, education for early childhood is the provision of stimuli (stimulation) from the immediate environment is needed to optimize children's abilities.

Every child is expected to achieve optimal growth and development. In order for all aspects of child development at kindergarten age to develop in an integrated and optimal way, education is needed that can provide stimulation and services to aspects of gross and fine motor skills development, creative intelligence, thinking power, cognitive, self-concept, discipline, independence of art, morals, social, emotional and language also religious values in accordance with the uniqueness and stages of development of each child.

One aspect that must be developed in early childhood is the cognitive aspects, because cognitive aspects are very important for children to learn the next level of life as well as the future. The cognitive aspects related to the level of intelligence that marks a person with various interests, especially directed at ideas and learning. With cognitive development, children are expected to recognize the concept 
of linking cause and effect, assessing and considering an event.

Specifically in the field of science introduction, the basic competencies that children must possess are being able to get to know simple concepts and science process skills that related to daily life. Science process skills for early childhood include observation, classification, comparing, measuring, communicating, experimenting, thinking, applying, and connecting. (Agustini, et al, https://ejournal.undiksha.ac.id, 7/2/2018).

One of learning resource that can be use is textbooks. So that textbooks are appropriate and close to the child's learning environment, one way to do this is to develop textbooks. The development of textbooks is carried out with due regard to the objectives of science learning for early childhood in kindergarten according to Leeper (1994) more clearly can be seen in table 1 below:

TABLE 1. TEXTBOOK SUPPORT

\begin{tabular}{|c|l|l|}
\hline No. & \multicolumn{1}{|c|}{$\begin{array}{c}\text { Science Learning } \\
\text { Objectives for Early } \\
\text { Childhood }\end{array}$} & \multicolumn{1}{c|}{ Book Carrying Capacity } \\
\hline 1 & $\begin{array}{l}\text { To know the concepts related } \\
\text { to life and be skilled in } \\
\text { solving problems. }\end{array}$ & $\begin{array}{l}\text { Less support, because the } \\
\text { concepts presented are not put } \\
\text { forward based on the child's } \\
\text { environmental conditions. And } \\
\text { it is not accompanied by the } \\
\text { availability of textbooks as a } \\
\text { guide for teachers in teaching. }\end{array}$ \\
\hline 2 & $\begin{array}{l}\text { Having scientific attitudes, } \\
\text { such as being able to gather } \\
\text { information. }\end{array}$ & $\begin{array}{l}\text { Less support, because it is not } \\
\text { accompanied by a teaching } \\
\text { guide that can be used by } \\
\text { teachers in teaching. }\end{array}$ \\
\hline 3 & $\begin{array}{l}\text { Children get better scientific } \\
\text { knowledge and information } \\
\text { also fun. }\end{array}$ & $\begin{array}{l}\text { Supporting, because it can hone } \\
\text { children's thinking skills. }\end{array}$ \\
\hline 3 & $\begin{array}{l}\text { Cultivate interest in learning } \\
\text { and exploring different } \\
\text { sciences and found in the } \\
\text { environment and surrounding } \\
\text { nature. }\end{array}$ & $\begin{array}{l}\text { Less support, because it is } \\
\text { presented in a textbook that } \\
\text { does not involve group work } \\
\text { among fellow students. }\end{array}$ \\
\hline
\end{tabular}

Based on Table 1, it can be said that the textbooks used do not support the ability of students to recognize the concepts of science learning that relate to students' daily lives and are close to their environment, not expressed in-depth. Aside from that, textbooks are needed that can be used by teachers as a guide in teaching science to early childhood. So that it can help teachers to hone the ability to think logically and critically, curiosity, inquiry, solve problems and foster the ability to connect cause and effect on children.

The development of a textbook should be able to improve the effectiveness of student learning, the effectiveness of students in participating in learning will increase if supported by textbooks that are in accordance with the competencies to be achieved that relate to experimental learning based science. Based on the results of initial observations conducted by researcher in kindergarten of TK IT MTTQ School Sampe Cita District of Kutalumbaru textbooks that are used as a dominant learning resource provide only child activity sheets, without assessment criteria sheets for the material that the child has learned and without textbooks that can be use by the teachers as a guide for teaching. The impact of the use of textbooks is the lack of student recognition of science learning that is close to the student environment, so learning does not lead to providing direct and meaningful experience.

Therefore, the development of experimental science-based textbooks which is fun for early childhood (5-6 years) is very important, because being able to foster student interest in learning without coercion and being able to connect the learning process with the realities of student environment with learning material. The development of a fun experiment-based science textbook is one of the efforts to meet the needs of teachers and students for textbooks that are in accordance with the core competencies and basic competencies to be achieved.

Based on the results of the analysis of teacher needs that have been done by collecting data through a questionnaire the needs of teachers can be said that most teachers knew that science-based learning is experimental. However, teachers prefer to use textbooks that are available at school even though very little material is provided that introduces science.

This condition is increasingly making the introduction of science in early childhood will be ignored, so students will not know that learning science is very fun and close to the child's environment. From the results of the analysis of the teacher's need for experimental experiment-based science textbooks that are fun for early childhood (5-6 years), it is necessary to develop a fun experiment-based science textbook. The introduction of science to children from an early age has the potential to help the cognitive development of students who are needed by children in the future. Thus, it is expected that student effectiveness will increase in following the learning process.

\section{METHODOLOGY OF RESEARCH}

The method used in this research is research and development methods (Research and Development/ R\&D). As explained by Sugiyono in his book (Sugiyono, $2015: 407$ ) that research and development method (R/D) is a research method used to produce certain products and test the effectiveness of those products. This method is used because it develops textbooks for group B, based on the 2013 curriculum which in its application of K13 Early Childhood Education Program demands a change of old mindset to a new mindset. Where with the development of this textbook teaching and learning process in early childhood can be done with active activities where children can do a lot of things to gain experience through science-based introduction to experiments.

a. Research Design and Development

Research and development methods is a research method used to produce certain products and test the effectiveness of these products. (Sugiyono, 2015:407). The research design used in this study was a 4-D (Four D Models) model development research design according to Thiagarajan.

1. Defining stage (Define)

The define stage is the stage for assigning and defining the terms of learning. This stage includes five main steps, namely 
needs analysis, learner analysis, concept analysis, and specifying instructional objectives.

\section{a) Concept Analysis}

In the material analysis stage, the material used is intended for the development of scientific abilities at the age of 5-6 years can be presented in the following Table 2 :

TABLE 2 MATERIAL USED IS AIMED AT COGNITIVE DEVELOPMENT

\begin{tabular}{|l|l|}
\hline \multicolumn{1}{|c|}{ Development Goals } & \multicolumn{1}{|c|}{ Materials } \\
\hline $\begin{array}{l}\text { Shows explorative and probing } \\
\text { activities. }\end{array}$ & $\begin{array}{l}\text { Conduct simple experimental } \\
\text { activities on a science object. }\end{array}$ \\
\hline $\begin{array}{l}\text { Smooth thinking is the ability to } \\
\text { produce ideas (fluency) }\end{array}$ & $\begin{array}{l}\text { Invite children to do science } \\
\text { learning activities. }\end{array}$ \\
\hline $\begin{array}{l}\text { Flexibility is the ability to use } \\
\text { various approaches to overcome } \\
\text { various problems }\end{array}$ & $\begin{array}{l}\text { Provide interpretation of } \\
\text { experimental learning based on } \\
\text { science using media. }\end{array}$ \\
\hline $\begin{array}{l}\text { Being able to think logically by } \\
\text { recognizing } \\
\text { relationships. }\end{array}$ & $\begin{array}{l}\text { Perform simple experiments that } \\
\text { can stimulate the development of } \\
\text { cognitive aspects of children. }\end{array}$ \\
\hline
\end{tabular}

In task analysis, cognitive development with children's scientific abilities is stimulated in simple experimental activities by conducting experimental activities that appear when the child can coordinate the eyes with his hands, observe the object being studied, understand and be able to carry out instructions that have been given and be able to communicate the knowledge that has been obtained. Before the experiment based science learning activities are carried out, firstly children are invited to get to know various types of plants to build initial knowledge and the purpose of learning activities based on experimental science.

Then the child will show one or more of the existing collection of vegetables as a type of vegetable that is preferred by the child, then invite the child to imagine the taste of several types of vegetables, such as spinach, carrots or mustard greens. Experimental-based science learning provides opportunities for children to interact directly with their surroundings (Utami, A. 2013:522).

The specification of the formulation of learning objectives is carried out to describe the indicators of achievement of learning outcomes into more specific indicators, which are adjusted based on the results of the analysis of the material and the tasks that have been done previously. The evaluation is seen when the child can observe, coordinate the eyes with his hands, understand instructions and be able to communicate the knowledge he has acquired when the science-based experimental process is carried out.

\section{b) Learner Analysis (Student Analysis)}

Student analysis is a very important step to do at the beginning of planning. Analysis of students is done by observing the characteristics of students. This analysis is done by considering the characteristics, abilities, and experiences of students, both as a group and as individuals. Student analysis includes the affective, cognitive, student psychomotor development, and student learning environments.

\section{c) Concept Analysis}

Concept Analysis according to Thiagarajan, et al (1974) conducted to identify the main concepts to be taught, arrange them in a hierarchical form, and detailing individual concepts into critical and relevant things. Concept analysis is relate to the analysis of the material students will learn, namely by creating a concept map that will facilitate students in understanding the theme of the lesson.

d) Task Analysis

Task analysis aims to identify the main skills that will be learned by researcher and analyze them into a set of additional skills that may be needed. This analysis ensures a thorough review of the tasks in the theme of the lesson.

e) Specification of Learning Indicator

The formulation of learning objectives is useful for summarizing the results of concept analysis and task analysis to determine the behavior of the research object. The collection of objects will be used as a guide in preparing tests and designing learning tools that will be used by researcher. Indicators or learning objectives must be adjusted to basic competencies in accordance with the applicable curriculum at the research site. The basic competencies that will be developed in these teaching materials are as follows :

TABLE 3. BASIC COMPETENCIES AND ACTIVITY MATERIALS

\begin{tabular}{|c|l|}
\hline $\begin{array}{c}\text { Basic Competencies } \\
\text { Meligious Values and } \\
\text { Moral }\end{array}$ & $\begin{array}{l}|c| \\
\text { Activity Materials } \\
\text { environment is Gurrounding } \\
\text { creation }\end{array}$ \\
\hline $\begin{array}{c}\text { Physical Motor } \\
2.1\end{array}$ & $\begin{array}{l}\text { Conduct simple } \\
\text { experimental activities }\end{array}$ \\
\hline $\begin{array}{c}\text { Cognitive } \\
2.2\end{array}$ & $\begin{array}{l}\text { Get used to exploratory, } \\
\text { how to ask, how to get } \\
\text { answers. } \\
\text { - form two dimensions. }\end{array}$ \\
\hline $\begin{array}{c}\text { Social-Emotional } 4.6 \\
2.6\end{array}$ & $\begin{array}{l}\text { Rule of the game } \\
\text { Language }\end{array}$ \\
\hline 3.12 & $\begin{array}{l}\text { How to respond } \\
\text { appropriately } \\
\text { hearing a teacher's story. } \\
- \text { Communicate their } \\
\text { opinion based on what is } \\
\text { seen. }\end{array}$ \\
\hline Art & $\begin{array}{l}\text { Create various works } \\
\text { and art activities }\end{array}$ \\
\hline
\end{tabular}

2. Designing Stage (Design)

At this stage, the step that must be passed is to prepare an initial draft to design an experimental science-based textbook prepared for early childhood learning. The learning tools are in the form of textbooks, children's activity sheets, daily learning implementation plans (RPPH) and evaluation or assessment sheets.

To assess learning outcomes, a research instrument in the form of learning outcomes tests was also designed. In addition, this research will also design other research instruments namely : the observation sheet of children's 
activities, teacher observation sheet in managing learning, and teacher's questionnaire responses and assessment instruments consisting of self-assessment observation sheets, written tests, and performance observation sheets.

The steps in this design stage are as follows :
a. Draft Test
b. Media Contruction
c. Format Selection

\section{Development Stage (Develop)}

This stage aims to produce a product that is learning tools using authentic assessments that have been revised by experts and are considered feasible. This stage includes Draft I, namely: designing learning tools, which are then reviewed by experts, next to Draft II, namely: make a revision I of the Teaching Materials that have been reviewed by experts, then the revised and good assessment according to the expert, then tested and analyzed. Activities in Draft III, namely: data that has been analyzed are revised again, then proceed to trial II and more analyzed.

\section{Instrument of Collecting Data}

The instrument used as a data collector that is the form of making an observation expert validation sheet or an observation instrument in learning science. Checklist observation sheet covers the ability to observe, understand and communicate in learning about the plants theme during research.

\section{Data analysis technique}

Analysis of the data that used in this research is : 1) To analyzing the validity of science-based science textbooks, and 2) To analyzing of learning outcomes before and after using textbooks.

The feasibility analysis of the textbook used the results given by experts, figures, and practitioners. The rating scale used on the validation questionnaire sheet is as follows :

TABLE 4. CHANGING QUALITATIVE VALUES INTO QUANTITATIVE VALUES

\begin{tabular}{|c|c|}
\hline Values & Rate \\
\hline Very Good & 4 \\
\hline Good & 3 \\
\hline Less & 2 \\
\hline Very Less & 1 \\
\hline & Djemari Mardapi (2008:122)
\end{tabular}

Then the resulting score is analyzed using the percentage score using the formula :

\section{Percentage Score $=$

$$
\frac{\text { Number of scores obtained }}{\text { Total Score }} \quad 100 \%
$$$$
\text { Total Score }
$$

(Akbar, 2015 :95)

Calculation of validation data using the formula above will produce a number in the form of percent, then converted to a classification in the form of a percentage, the next step is to determine the feasibility of the textbook based on the results of the research carried out. Then categorized with qualitative sentences as listed in Table 4 this below :

TABLE 5. PERCENTAGE LEVEL OF TEXTBOOK VALIDITY (AKBAR, 2015: 40-41)

\begin{tabular}{|c|c|c|}
\hline Num. & $\begin{array}{c}\text { Validity } \\
\text { Criteria }\end{array}$ & Validity Level \\
\hline 1 & $\begin{array}{c}85,01 \%- \\
100,00 \%\end{array}$ & $\begin{array}{c}\text { Very good, or can be used } \\
\text { without revision }\end{array}$ \\
\hline 2 & $\begin{array}{c}70,01 \%- \\
85,00 \%\end{array}$ & $\begin{array}{c}\text { Good, or it can be used but } \\
\text { needs a little revision }\end{array}$ \\
\hline 3 & $\begin{array}{c}50,01 \%- \\
70,00 \%\end{array}$ & $\begin{array}{c}\text { Very less, It is recommended } \\
\text { not to use it because it needs } \\
\text { massive revision }\end{array}$ \\
\hline 4 & $\begin{array}{c}01,00 \%- \\
50,00 \%\end{array}$ & Very Bad, or it can't be use \\
\hline
\end{tabular}

To determine the feasibility of textbooks using a Likert scale, by using a Likert scale measurement, then the variable will be measured and translated into indicator variables (Sugiyono, 2015:135).

The data obtained are data in the form of numbers which are further categorized according to the Likert scale measurement that is calculating the average score of answers from all respondents. The results of the feasibility test on the textbooks that develope in this study are categorized into five categories. Feasibility in this aspect of research developing a fun experimental science-based textbook for early childhood (5-6 years) using Table 2 below :

\section{TABLE 6. PRACTITIONERS' RESPONSES TO TEXTBOOKS}

\begin{tabular}{|c|c|}
\hline Average Number & $\begin{array}{c}\text { Classification of Student } \\
\text { Responses }\end{array}$ \\
\hline $4,2 \mathrm{~s} / \mathrm{d} 5,0$ & Excellent \\
\hline $3,4 \mathrm{~s} / \mathrm{d} 4,2$ & Good \\
\hline $2,6 \mathrm{~s} / \mathrm{d} 3,4$ & Not Good \\
\hline $1,8 \mathrm{~s} / \mathrm{d} 2,6$ & Bad \\
\hline $1,0 \mathrm{~s} / \mathrm{d} 1,8$ & Very Bad \\
\hline
\end{tabular}

(Source : Widoyoko, 2014 : 112-114)

\section{Data Analysis of the Effectiveness of Science Textbooks Based on Fun Experiments}

Analysis of the effectiveness of experimental learningbased learning textbooks in increasing students' cognitive development aims to make a decision on whether further trials need to be made in the stage of developing experimental-based science textbooks. The effectiveness of the development of experimental based learning books that use is determined based on achieving indicators of the development of students' cognitive abilities, achievement indicators of cognitive development of students, as well as students and teacher responses. The test results used are then analyzed to see the achievements of students' cognitive development in experimental-based learning books. The formula used is :

$$
\mathrm{KB}=\frac{\mathrm{T}}{\mathrm{Tt}} \times 100 \% \quad \text { (Trianto, 2007:241) }
$$


Explanation:

$\mathrm{KB}$ : Ketuntasan Belajar (Completeness Learning)

$\mathrm{T}$ : Jumlah skor yang diperoleh peserta didik (The Number of Scores Obtained by Students)

$\mathrm{Tt}$ : Jumlah Skor Total (The Number of Scores Total)

\section{RESEARCH RESULTS AND DISCUSSION}

The study was conducted at TK IT MTQ School which is located at Jl. Lush Glugur, Sampe Cita Village, District of Kutalimbaru, Regency of Deli Serdang.

Data analysis is in the form of a validation test or assessment from the reviewer and a practical test by a material expert lecturer. The reviewer results on all aspects show that the textbooks are in good criteria with an average score 3.3. The highest result of data analysis lies in the accuracy of the facts and concepts of the author in making the textbook. The lowest average score lies in the aspect of the breadth of the material with an average score of 3.0.

\section{For Sub Component}

1. Material suitability with Competency Standards and Basic Competence

a. Breadth of Material

The material presented outlines the minimum substance (facts, concepts, principles and theories) contained in Indicators \& Basic Competencies, a value of 3 points in obtained.

b. Material Depth

The level of difficulty is adjusted and the complexity of the material is adjusted to the level of cognitive development of students, a value of 3 points in obtained.

\section{Material Asccuracy}

a. Accuracy of Facts dan Consept

The material (including examples and exercises) that presented in accordance with the truth of concepts and facts and does not cause multiple interpretations a value of 4 points in obtained

b. Accuracy of illustration

The illustrations given are in accordance with the facts and the illustrations are explained in proportional size and shape, a value of 3 points in obtained.

\section{Learning Support Materials}

a. Conformity with the development of science and technology

Material (including examples and exercises) is in accordance with the development of science and technology, a value of 4 points in obtained.

b. Recency of features, examples and references

Features (including examples and exercises) reflect events and environmental conditions of students, a value of 3 points in obtained

c. Contextual

Description, the examples and exercises presented come from the immediate environment and are familiar with the daily lives of students, a value of 3 points in obtained.
From the expalanation above, it can be concluded that the aspect of material relevance obtained at number 23.00 is included in the good category and the figure of $82.14 \%$ is obtained so that it is included in the good criteria (feasible), based on explanation it can be seen that the assessment of material relevance aspects in the diagram :

\section{Matter Relevanace}

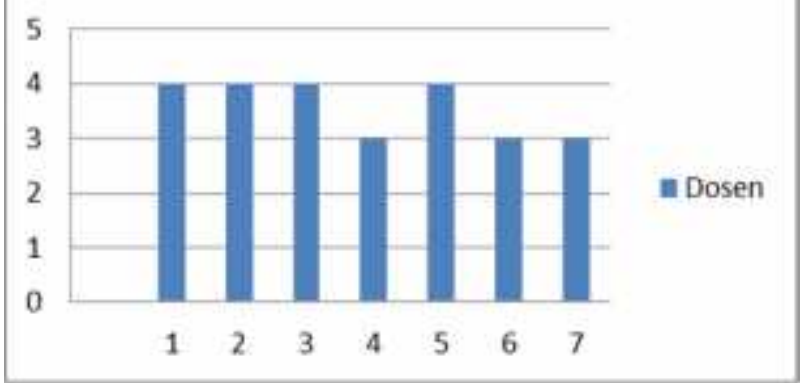

Fig.1. Expert Rating on the Aspect of Material Relevance

TABLE 7. RECAPITULATION OF VALIDATION RESULTS FOR THE ASPECT OF MATERIAL RELEVANCE OF LEARNING DESIGN EXPERT

\begin{tabular}{|c|c|c|c|c|}
\hline No & Sit-Onupus.ne & Iüicelos & $\begin{array}{l}\text { IAroti } \\
\text { Antzmeit }\end{array}$ & Exalansivin \\
\hline 1 & $\underset{\substack{\text { Sullygilit of } \\
\text { Camafis }}}{ }$ & 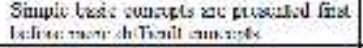 & 5 & Ix:elient \\
\hline 2 & 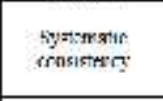 & 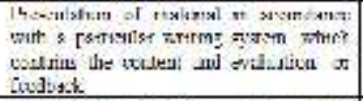 & 5 & Exoctloul. \\
\hline 3 & Student cersecti & 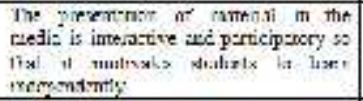 & $\Sigma$ & Ix:elient \\
\hline 4 & $\begin{array}{c}\text { 12exticp zoncest } \\
\text { thitit }\end{array}$ & 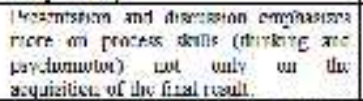 & 4 & Coct \\
\hline ? & $\begin{array}{l}\text { Variatise in } \\
\text { xesuliasu }\end{array}$ & 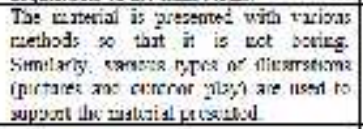 & 4 & cisec \\
\hline 6 & 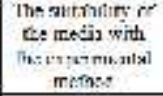 & 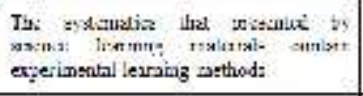 & 5 & Dr:elient \\
\hline 7 & Eralustist & 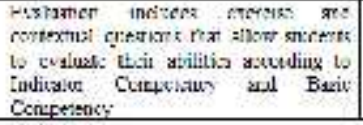 & 4 & Goed \\
\hline
\end{tabular}

By using the same formula, the material expert's assessment of the learning design obtained good and decent results. In the aspect of learning design has a total of 7 indicators and obtained an assessment of 25 and a percentage of 89.28. based on Table 7 assessment of learning design aspects can be seen in the diagram below : 


\section{Learning Design Aspects}

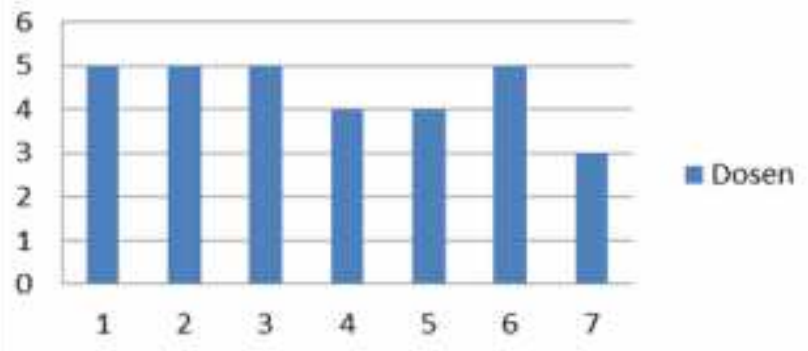

Figure 3.2 Expert Material Assessment on the Relevance Aspects of Learning Design

The results of the practicality of learning design there are 4 highest values, namely the aspect of suitability concept, systematic consistency, student centered and variations in presentation with a score of 15.0. The lowest score results are in the evaluation or the 7 th variable.

\section{DISCUSSION}

Based on the results of the validation of the textbook assessed by reviewers, there are 7 aspects of assessment namely the breadth of material, the depth of material, the accuracy of facts and concepts, the accuracy of the illustrations, the conformity with the development of science and technology, the recency of features, examples, references and contextual. The highest value is in the aspect of the author's approach in making textbooks. This shows that the book-making approach is appropriate for the age of child development at the age of 5-6 years. The making of this fun experiment-based science textbook is used to provide convenience both from the side of the teacher and students so that it can more easily provide direct and meaningful experience in carrying out the learning process and the introduction of science in early childhood aged 5-6 years.

The results of this study also indicate a weakness in terms of preparing the evaluation and reference sources. The low evaluation formulation is caused by not having the right instrument to measure the cognitive abilities of children aged 5-6 years. Lack of reference literature sources in making early childhood evaluation sheets is the main obstacle in the preparation of evaluation sheets in this textbook. Research reference resources for the development of fun experimentbased science textbooks are still limited, so difficulties arise in making the initial reference point for developing textbooks.

In making this textbook there are still other obstacles. The obstacle that faced is the difficulty in conducting reviewer assessments in accordance with the area of expertise and practicality test. There are 3 reviewers for this book, two from the material expert and one from the learning design. For the research subjects only 36 students with 4 teachers as respondents of practicality test books. Based on the existing obstacles and limitations, several solutions can be proposed, that in the future, it requires in-depth study and reference literatures in the research process. Better prepared the observation locations in accordance with the provisions of quantitative research with more ideal samples, as well as an increase in the number of reviewers with experts in the field of science learning methodology in early childhood.

\section{CONCLUSIONS AND SUGGESTIONS}

Conclusions

Based on the analysis of product design and data it can be stated in the development of experimental science-based textbooks for early childhood education, it can be concluded as follows :

1. Textbooks have a validity assessment with good categories from all aspects.

2. Fun experiment based science textbooks for early childhood have a good approach in making textbooks so that students are invited to learn with direct and meaningful experiences.

Suggestions

Based on the results of research and discussion, it can be stated that the scope of research is still limited. It is necessary to study the development of science textbooks to a wider domain. Then the need for in-depth study in analyzing the needs of developing science textbooks, and the need to increase research on the development of PAUD (Education for Early Childhood) textbooks to increase reference sources for development.

\section{REFERENCES}

[1] Akbar.Sa'dun. 2015. Instrumen Perangkat Pembelajaran. Bandung : Rosdakarya

[2] Trianto. 2007. Model-Model Pembelajaran Inovatif Berorientasi Konstruksivistis. Jakarta : Prestasi Pustaka.

[3] Suyadi. 2010. Psikologi Belajar PAUD (Pendidikan Anak Usia Dini). Yogyakarta : Pedagogia.

[4] Kementrian Republik Indonesia. 2015. Undang-undang Republik Indonesia Nomor 20 Tahun 2003 tentang Sisdiknas \& Peraturan Pemerintah R.I Tahun 2015 tentang Standar Nasional Pendidikan serta Wajib Belajar. Bandung : Citra Umbara.

[5] Thiagarajan, S. Semmel, \& D.S. Semmel, M. 1974. Instructional Development for Training Teachers of Exceptional Children. A Sourse Book. Blomington: Central for Innovation on Teaching The Handicapped.

[6] Trianto. 2007. Model-Model Pembelajaran Inovatif Berorientasi Konstruksivistis. Jakarta : Prestasi Pustaka.

[7] Utami, Ade Dwi, dkk. 2013. Modul PLPG Pendidikan Anak Usia Dini Konsorsium Sertifikasi Guru PAUD. Jakarta, Tersedia di http://sertifikasi.fkip.uns.ac.id/modul/PAUD/1\%20PAUD.pdf (Downloaded on January 10th 2017) 